\title{
Evaluation of microalgal and formulated diets for the culture of the New Zealand pipi clam Paphies australis
}

\author{
Nawwar Z. Mamat • Andrea C. Alfaro
}

Received: 26 July 2013/Accepted: 5 November 2013/Published online: 18 March 2014

(C) The Author(s) 2014. This article is published with open access at Springerlink.com

\begin{abstract}
A set of feeding trials was carried out for different microalgal species and processed diets for the culture of the New Zealand pipi, Paphies australis. Five microalgal species (Isochrysis galbana clone T-ISO, Pavlova lutheri, Tetraselmis suecica, Chaetoceros muelleri, and Thalassiosira pseudonana clone $3 \mathrm{H}$ ) and three formulated diets (baker's yeast, wheat flour, and corn flour) were fed to spat, juvenile, and adult pipi for 21 days. Unfed pipi were used in the control group. The spat and juvenile pipi showed the major shell increase with I. galbana, while the greatest wet weight increase was obtained with $P$. lutheri. The shells of adult pipi grew better with corn flour and $P$. lutheri-fed group obtained the greatest wet weight. Results of proximate analysis in adult pipi revealed that proteins and lipids were accumulated in the tissue for all fed groups, while carbohydrate levels depleted in all treatments including the control group. It is suggested that the gonads have developed during the experiment.
\end{abstract}

Keywords Clam aquaculture $\cdot$ Microalgae diets $\cdot$ Formulated diets $\cdot$ Paphies australis $\cdot$ Pipi

\section{Introduction}

One of the main constraints in bivalve rearing for aquaculture purposes is the production of appropriate diets, including live (microalgae) and formulated feeds. The high variability in nutritional requirements among bivalve species, even within the same genus has made it difficult to generalise diet formulation techniques across species (Coutteau and Sorgeloos 1992). Thus, new cultured species require considerable background and experimental research to identify the best diets for cost-effective stock production.

Numerous studies have investigated the nutritional value and feeding applications (e.g., ration size, cell concentration) of a number of microalgal species (Webb and Chu 1983; Hooker 1995; Galley et al. 2010). Many of these microalgal species are regularly used in hatchery production, including Tetraselmis suecica, T. chuii, Nannochloropsis atomus, N. oculata, Isochrysis galbana (T-ISO clone), Pavlova lutheri, P. salina,

N. Z. Mamat $(\square)$

Universiti Teknologi MARA (UiTM), 40450 Shah Alam, Selangor, Malaysia

e-mail: nawwar353@perlis.uitm.edu.my

N. Z. Mamat

Faculty of Applied Sciences, Universiti Teknologi MARA Perlis, 02600 Arau, Malaysia

A. C. Alfaro

School of Applied Sciences, Faculty of Health and Environmental Sciences, Auckland University of Technology,

Private Bag 92006, Auckland 1142, New Zealand 
Chaetoceros calcitrans forma pumilus, Chaetoceros muelleri, Skeletonema costatum, and Thalassiosira pseudonana. Depending on their nutritional contents, a combination of microalgal species often is used to provide a balanced diet for larvae and juvenile bivalves (Hooker 1995; Ceron-Ortiz et al. 2009). For example, in the lion-paw scallop Lyropecten subnodosus, spat fed P. lutheri/C. muelleri mixture diet recorded the major increases in growth (Ceron-Ortiz et al. 2009). Similarly, growth of the blue mussel Mytilus edulis veliger larvae fed mixed diets outperformed single species diets (Galley et al. 2010). However, the cultivation of microalgae is labour extensive and expensive. Thus, the replacement of live microalgae with low-cost alternative diets has been used for a number of bivalve species (Perez-Camacho et al. 1998; Pales-Espinosa and Allam 2006; Mazon-Suastegui et al. 2008; Nevejan et al. 2008).

Substitutions of microalgae with processed diets, such as yeast and plant-based flours, have been shown to be effective for the cultivation of Tapes philippinarum (Caers et al. 1999), Ruditapes decussatus (Albentosa et al. 1999), and Mercenaria mercenaria (Epifanio 1979). Albentosa et al. (1999) in their study with T. philippinarum spat have successfully replaced up to $50 \%$ of the daily food ration with wheat germ flour. Within the 6 weeks of culture period, spat fed 50:50 I. galbana and wheat germ flour mixed diet obtained a final dry weight of $12.61 \mathrm{mg}^{-1}$ ind $^{-1}$, showing no significant difference $(p>0.05)$ with spat fed exclusively I. galbana (14.09 $\mathrm{mg} \mathrm{ind}^{-1}$ ). While these studies provide good information regarding the potential uses of various live and formulated diets for bivalve rearing, experimental studies on the effects of specific diets on the growth of new aquaculture species are needed to elucidate the most appropriate and cost-effective diets.

The pipi clam, Paphies australis, is one of the most widely distributed and common infaunal clams in New Zealand. This species is endemic to New Zealand, and constitutes a thriving fisheries industry for the local market. A number of studies have been focused mainly on biological and ecological aspects of wild populations, including the reproduction and larval development (Hooker 1995), population dynamics (Hooker1995; Hewitt et al. 1997; McLeod and Wing 2008), and burrowing behaviour (Hull et al. 1998). While P. australis has one of the best aquaculture potentials of any New Zealand clam, there is a significant lack of information regarding its nutritional requirements and the hatchery conditions necessary for its cultivation. Thus, the purpose of this study is to assess the survival and growth performance of spat, juvenile and adult pipi clams fed a range of microalgal and formulated diets in the laboratory.

\section{Materials and methods}

Experimental setup

Pipi clams of a wide range of sizes were collected from Waiwera Beach, Northern Auckland $\left(-35.550^{\circ} \mathrm{N}\right.$ $174.717^{\circ} \mathrm{W}$ ). The animals were taken to the Auckland University of Technology (AUT) aquaculture laboratory, where they were acclimatised for 3 days before the start of the experiment. Three clam size classes were selected as: spat (0-10.0 $\mathrm{mm}$ in shell length), juveniles $(15.0-25.0 \mathrm{~mm}$ in shell length), and adults (30.0-40.0 mm in shell length). Three replicate tanks (2-L tanks $178 \mathrm{~mm}$ length $\times 130 \mathrm{~mm}$ width $\times 120 \mathrm{~mm}$ height) were used for each feeding treatment and for each of the three clam size classes. Each tank contained 30 spat, 20 juveniles, or 10 adults per tank. All individuals were marked with a number on both valves so that individual shell lengths and weights could be recorded at the start and at the end of the experiment. Maximum shell lengths were measured with a vernier calliper to the nearest millimetre. Wet weights were obtained while individuals were submerged in the water within each experimental container. A tray connected to a bottom hook on a balance supported above each experimental container was placed underwater within each tank. After zeroing the balance, each animal was placed on the submerged tray to obtain its wet weight. Accurate wet weights were achieved with this method, since the clams were not removed from the water, thus avoiding water content biases.

The feeding treatments included five microalgal species (T-ISO clone Isochrysis galbana, Pavlova lutheri, Tetraselmis suecica, Chaetoceros muelleri, and 3-H clone Thalassiosira pseudonana), three formulated diets (yeast, wheat flour and corn flour), and a starved group for each of the three size classes. The feeding rations were 2, 4, and $6 \%$ (dry food weight/live animal weight/tank) for spat, juvenile and adult clams, respectively. Feeding was conducted daily after a full water exchange for an experimental period of 21 days. For all tanks, the water salinity was maintained at $35 \mathrm{ppt}$ and the temperature at $17-18{ }^{\circ} \mathrm{C}$ throughout the experiment. 
Constant aeration was maintained with individual airflow lines to each tank. The tanks were cleaned daily to remove solid waste products.

Experimental diets

Microalgal stocks were obtained from CSIRO Microalgae Research Centre, Australia and grown in $15 \mathrm{~L}$ carboys at a constant temperature of $18{ }^{\circ} \mathrm{C}$ and exposed to a 12L:12D illumination cycles. The cultures were enriched with f/2 medium as described by Guillard (1975). The baker's yeast granules were previously ground to a powder form and sieved through a $20-\mu \mathrm{m}$ sieve. The baker's yeast (Edmonds Ltd.), corn flour (Edmonds Ltd.), and wheat flour (Woolworths Ltd.) were suspended in seawater before being poured into the tanks to avoid lumping.

The dry weight of microalgal cells was determined by filtering the culture through $0.45-\mu \mathrm{m}$ pore-size membrane filters. The filters were then rinsed with $0.5 \mathrm{M}$ ammonium formate to eliminate salt residues (Epifanio 1979), and dried for $12 \mathrm{~h}$ at $100{ }^{\circ} \mathrm{C}$ (Table 1).

Proximate analysis

Proximate analysis (proteins, lipids, carbohydrates, ash and moisture) was performed in a group of adult clams at the start of the experiment (initial condition) and at the end of the experiment (final condition). Spat and juveniles provided insufficient materials to carry out the proximate analysis; therefore, only the adult clams were analysed for evaluating the nutritional benefit of each diet on the growth and body content of pipi. Three replicate samples of $1.0 \mathrm{~g}$ of dry tissue were used for each analysis.

Before the start of the feeding trial, 30 adult clams were frozen $\left(-20^{\circ} \mathrm{C}\right)$ to determine the initial proximate composition after 3 days acclimatisation. On day 21, following the growth measurements, the remaining adult clams were killed and the soft tissues were separated from the shell. The frozen tissues from the initial samples were thawed. The tissues (initial and final samples) were carefully blotted with absorbent papers to remove excess wetness prior to oven drying.

Moisture contents were determined by weight difference before and after drying the samples at $80{ }^{\circ} \mathrm{C}$ for $24 \mathrm{~h}$, and ash contents were obtained by burning the dry samples in a furnace at $600{ }^{\circ} \mathrm{C}$ for $2 \mathrm{~h}$ and cooled to room temperature in a desiccator. The differential weights were determined to be the ash content. Analyses of proteins were conducted following the Kjeldahl method as described by AOAC (2005). Lipids were quantified by a modification of Bligh and Dyer method (1959). Total carbohydrate contents were estimated by the difference between 100 and the sum of protein, lipid, and ash contents (FAO 2003). The same analysis was performed for three replicate samples of $1.0 \mathrm{~g}$ for each food type (five microalgae and three formulated feeds).

Statistical analyses

The SPSS version 15.0 (SPSS Inc.) statistical software was used to analyse the results. Growth (shell length and wet weight) and proximate composition (animals and feeds) data were analysed with parametric statistics. The proportions of shell lengths, wet weights, and proximate composition were transformed by arcsine square root transformation. All data met parametric assumptions after transformation. One-way analyses of variances (ANOVAs), followed by Tukey's HSD post hoc tests were conducted to determine the differences between the means of all treatments.

Table 1 Dry weight of the microalgal diets used in the experiment

\begin{tabular}{lc}
\hline Species & Dry weight $\left(\mathrm{pg}^{\mathrm{cell}} \mathrm{l}^{-1}\right)$ \\
\hline Isochrysis galbana (T-ISO) & $31.64 \pm 0.01$ \\
Pavlova lutheri & $110 \pm 0.02$ \\
Tetraselmis suecica & $172.81 \pm 0.03$ \\
Chaetoceros muelleri & $73.38 \pm 0.01$ \\
Thalassiosira pseudonana (3H) & $29.67 \pm 0.02$ \\
\hline
\end{tabular}




\section{Results}

Growth parameters

Clams within all three clam size classes increased in shell length and wet weight after being exposed to all treatments, except for those which were starved (Fig. 1). For all three size classes, shell lengths were significantly smaller for starved individuals, and significant weight losses were observed in all starved clams.

For the spat size class, the greatest length increase was for those fed on I. galbana $(1.21 \pm 0.10 \mathrm{~mm} / \mathrm{ind}$.) (Fig. 1a). However, this increase was not significantly different to the increase in spat fed P. lutheri (0.91 $\pm 0.09 \mathrm{~mm} / \mathrm{ind}.), C$. muelleri $(0.99 \pm 0.04 \mathrm{~mm} / \mathrm{ind}$.), and yeast $(1.00 \pm 0.18 \mathrm{~mm} / \mathrm{ind}$.) (ANOVA, $p<0.05)$. Wet weight gains were greatest for spat fed P. lutheri $(125.14 \pm 8.69 \mathrm{mg} / \mathrm{ind}$.), which was significantly different from the other treatments $(p>0.05)$ (Fig. 1b).

Juveniles had the greatest shell length increase when they were fed I. galbana $(1.72 \pm 0.18 \mathrm{~mm} / \mathrm{ind}$. $)$ (Fig. 1c). However, this increase did not differ significantly from the increments obtained by juveniles fed P. lutheri $(1.34 \pm 0.16 \mathrm{~mm} / \mathrm{ind}$.) and $T$. suecica $(1.31 \pm 0.44 \mathrm{~mm} / \mathrm{ind}$.) $(p>0.05)$. Tukey's test showed that juveniles fed T. pseudonana, yeast, wheat flour and corn flour were not significantly different to those fed with C. muelleri $(p>0.05)$. The greatest wet weight increase in juvenile pipi was recorded in animals fed $P$. lutheri (177.94 $\pm 8.12 \mathrm{mg} /$ ind.) $(p>0.05)$ (Fig. 1d).

For adult pipi, the greatest shell increase was observed in individuals fed corn flour $(0.79 \pm 0.29 \mathrm{~mm} / \mathrm{ind}$. $)$, which was not significantly different to adults fed $P$. lutheri $(0.53 \pm 0.09 \mathrm{~mm} / \mathrm{ind}$. $)$, yeast $(0.51 \pm 0.15 \mathrm{~mm} /$ ind.), and wheat flour $(0.59 \pm 0.10 \mathrm{~mm} / \mathrm{ind}).(p<0.05)$ (Fig. 1e). Adults fed P. lutheri $(167.74 \pm 22.34 \mathrm{mg} /$ ind.) achieved the greatest weight, but this value was not significantly different from those fed C. muelleri $(150.71 \pm 8.11 \mathrm{~mm} / \mathrm{ind})$, yeast $(131.75 \pm 7.89 \mathrm{~mm} / \mathrm{ind}$.), and corn flour $(145.88 \pm 12.09 \mathrm{~mm} / \mathrm{ind}$. $)$ $(p>0.05)$ (Fig. 1f).

\section{Mortality}

Relatively low mortality was observed after the 21-day experiment across all treatments for spat, juvenile, and adult pipi. Spat that was starved displayed the highest percent mortality at $22.22 \% \pm 3.85$ SD, followed by spat fed yeast (18.89\% \pm 3.85 SD). Spat fed I. galbana, T. suecica, C. muelleri, T. pseudonana and yeast treatments had pipi mortalities of $16.67 \% \pm 3.33 \mathrm{SD}, 17.78 \% \pm 8.39 \mathrm{SD}, 13.33 \% \pm 3.33 \mathrm{SD}$, $15.56 \% \pm 5.09 \mathrm{SD}$, and $14.44 \% \pm 1.92 \mathrm{SD}$, respectively. The lowest mortality was found in spat fed P. lutheri (12.22\% $\pm 3.85 \mathrm{SD})$ and wheat flour (12.22 \% \pm 1.92 SD) (Fig. 2a).

The highest mortality for juvenile pipi was found in animals fed on yeast (33.33\% \pm 2.89 SD), followed by I. galbana (25.00\% $\pm 10.00 \mathrm{SD})$ and wheat flour (25.00\% $\% 5.00 \mathrm{SD})$ (Fig. 2b). Juveniles fed T. suecica, C. Muelleri and T. pseudonana had the same percent mortality at $21.67 \%$. Meanwhile, juveniles fed C. muelleri and corn flour had a similar percent mortality at $20.00 \% \pm 5.00 \mathrm{SD}$. The lowest mortality was found in juveniles fed on $P$. lutheri (18.33\% \pm 2.89 SD).

For adult pipi, the highest mortality was for pipi fed yeast (33.33\% $\pm 5.77 \mathrm{SD})$, followed by adults fed wheat flour $(30.00 \% \pm 10.00 \mathrm{SD})$, and unfed $(30.00 \% \pm 10.00 \mathrm{SD})$. Adults fed T. suecica displayed a mortality of $26.67 \% \pm 5.77$ SD. Juveniles fed P. lutheri, C. muelleri and T. pseudonana showed the same mortality at $23.33 \% \pm 5.77 \mathrm{SD}$. The lowest mortality was found in adults fed corn flour $(16.67 \% \pm 5.77$ SD) (Fig. 2c).

Proximate composition of diets

The proximate composition data of all experimental diets (five microalgal and three formulated diets) are presented in Table 2.

In general, microalgal diets (I. galbana, P. lutheri, T. suecica, C. muelleri, and T. pseudonana) contained high protein and lipid contents, and low carbohydrate contents. In contrast, the formulated diets (baker's yeast, corn flour, and wheat flour) were low in protein and lipid contents, but high in carbohydrate contents. The highest protein content $(33.54 \pm 1.54 \%)$ among all diets was observed in T. pseudonana $(3 \mathrm{H})$, and the lowest protein content was observed in baker's yeast $(5.36 \pm 0.12 \%)$. The microalga $P$. lutheri contained the highest 

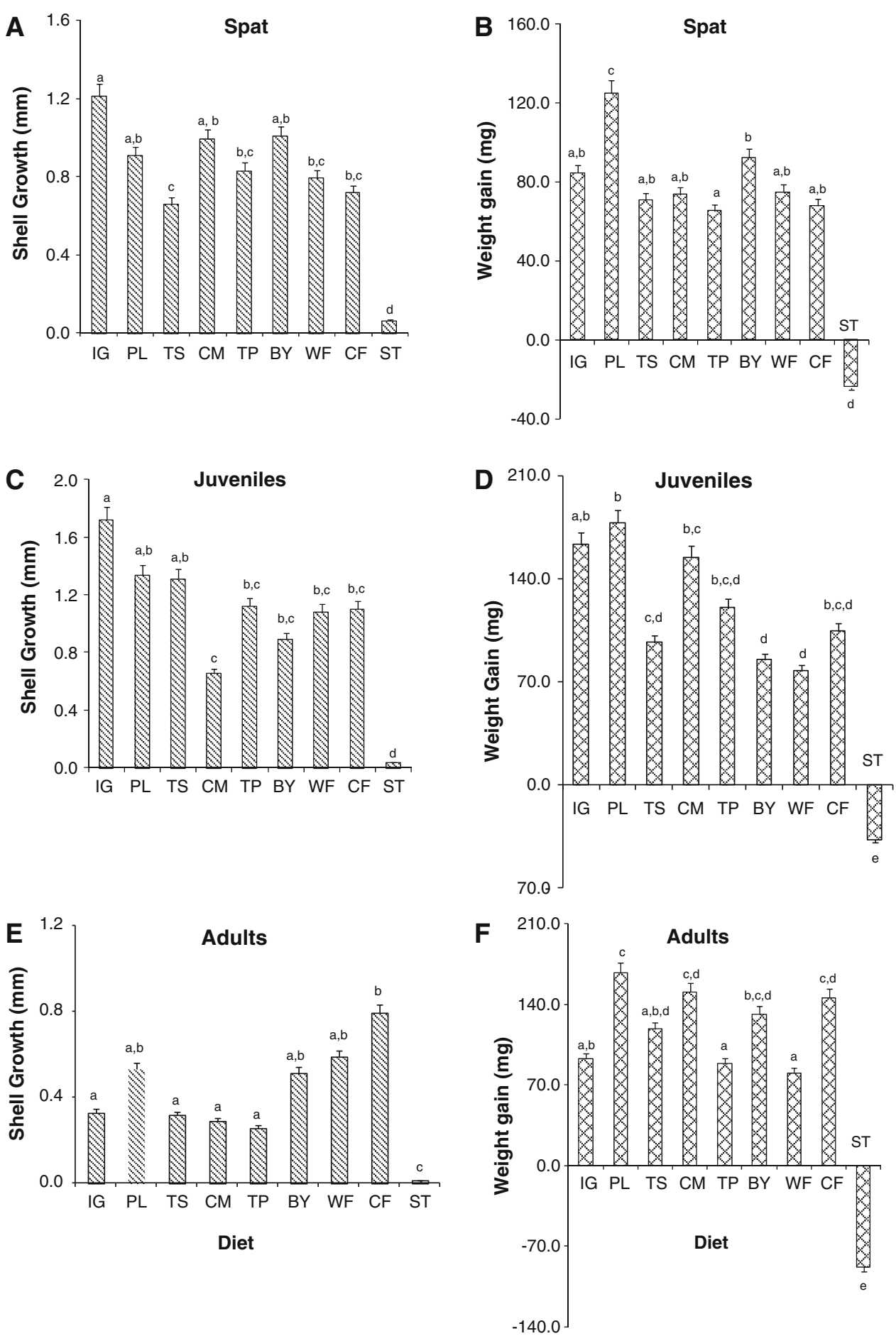

Fig. 1 Shell growth (mm) and weight gain (mg) for P. australis spat $(\mathbf{a}, \mathbf{b})$, juveniles $(\mathbf{c}, \mathbf{d})$, and adults $(\mathbf{e}, \mathbf{f})$ at the start and at the end of the 21-day feeding experiment. Data are for all treatment diets [I. galbana (IG), P. lutheri (PL), T. suecica (TS), C. muelleri (CM), T. pseudonana (TP), Baker's yeast (BY), wheat flour (WF), corn flour (CF) and starved (ST)]. The same letters over the error bars indicate non-statistical differences

proportion of lipids $(23.21 \pm 2.93 \%)$, while wheat flour had the lowest lipid content $(1.57 \pm 0.38 \%)$. Wheat flower had the highest amount of carbohydrates $(80.18 \pm 2.81 \%)$, and $P$. lutheri had the lowest carbohydrate content $(9.44 \pm 3.29 \%)$. Moisture and ash contents were highest for P. lutheri $(34.98 \pm 2.63 \%)$ and 

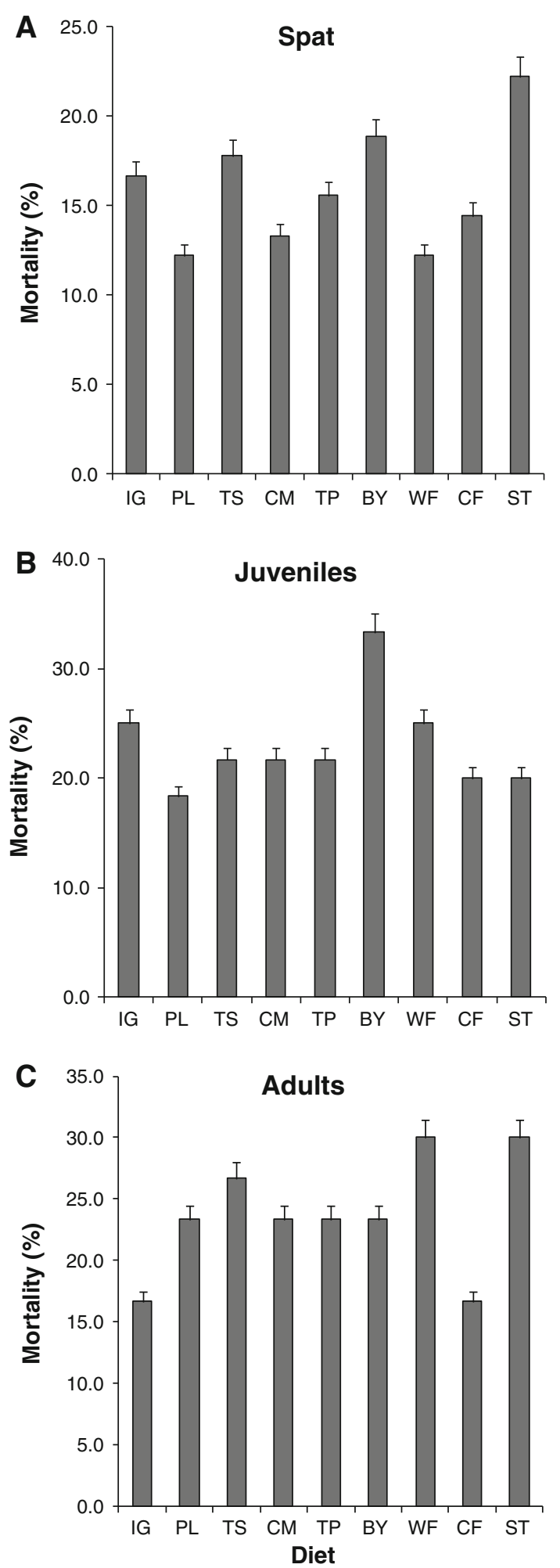

Fig. 2 Mortality of spat (a), juvenile (b), and adult (c) pipi during the 21-day feeding experiment. Clams were fed IG, I. galbana; PL, P. lutheri; TS, T. suecica; CM, C. muelleri; TP, T. pseudonana; Y, yeast; WF, wheat flour and CF, corn flour. Starved pipi (ST) was the control group. No statistical differences were observed among all treatments for spat, juvenile, and adult pipi. Error bars represent $95 \%$ confidence interval of the mean 
I. galbana $(10.85 \pm 0.30 \%)$, respectively, and lowest for corn flour $(8.49 \pm 1.47 \%)$ and wheat flour $(0.39 \pm 0.04 \%)$, respectively.

Proximate composition of animals

The proximate composition data of adult clams at the start and at the end of the experiment are shown in Table 3.

Protein and lipid contents were higher for the animals within all treatments at the end of the experiment, except the starved animals (ANOVA, $p<0.05$ ). The largest proportion of total protein content was found in adults fed $P$. lutheri $(33.75 \pm 0.87 \%)$. However, the protein content did not differ from that of those fed yeast $(p>0.05)$. All treatments, including the starved group, had significantly higher protein contents than the initial value.

Lipid contents were highest in adult pipi fed I. galbana $(6.13 \pm 0.53 \%)$, but the lipid content was not significantly different from those fed P. lutheri $(5.41 \pm 0.45 \%)$ and corn flour $(4.46 \pm 0.36 \%)(p>0.05)$. The starved group lost $11.8 \%$ of its lipid reserves, and that value was not significantly different from the initial lipid content $(p>0.05)$.

Carbohydrate contents were lower for all animals after the experimental period (including starved animals) compared with the initial values. However, these differences were not significant between the initial values and those of the animals fed T. suecica, C. muelleri, wheat flour, and the starved group $(p<0.05)$.

Table 2 Proximate composition (\%) of the microalgal and formulated diets (mean \pm SD)

\begin{tabular}{|c|c|c|c|c|c|}
\hline Diet & Protein & Total lipids & Total carbohydrates & Moisture & Ash \\
\hline Isochrysis galbana (T-ISO) & $21.30 \pm 0.59^{\mathrm{a}}$ & $19.06 \pm 0.65^{\mathrm{a}}$ & $19.59 \pm 1.86^{\mathrm{a}}$ & $29.19 \pm 2.51^{\mathrm{a}}$ & $10.85 \pm 0.30^{\mathrm{a}}$ \\
\hline Pavlova lutheri & $27.23 \pm 1.69^{\mathrm{b}, \mathrm{c}}$ & $23.21 \pm 2.93^{\mathrm{b}}$ & $9.44 \pm 3.29^{\mathrm{b}}$ & $34.98 \pm 2.63^{\mathrm{b}, \mathrm{c}}$ & $5.14 \pm 0.90^{\mathrm{b}}$ \\
\hline Tetraselmis suecica & $29.74 \pm 1.51^{\mathrm{c}, \mathrm{d}}$ & $10.90 \pm 0.60^{\mathrm{c}}$ & $18.68 \pm 3.49^{\mathrm{a}, \mathrm{c}, \mathrm{d}}$ & $33.71 \pm 1.67^{\mathrm{b}, \mathrm{c}}$ & $6.97 \pm 0.32^{\mathrm{c}}$ \\
\hline Chaetoceros mиеlleri & $31.79 \pm 0.48^{\mathrm{c}, \mathrm{d} . \mathrm{e}}$ & $15.63 \pm 1.37^{\mathrm{d}}$ & $20.34 \pm 3.02^{\mathrm{c}, \mathrm{d}}$ & $23.80 \pm 2.01^{\mathrm{d}}$ & $8.45 \pm 0.67^{\mathrm{d}}$ \\
\hline Thalassiosira pseudonana $(3 \mathrm{H})$ & $33.54 \pm 1.54^{\mathrm{d}, \mathrm{e}}$ & $18.86 \pm 1.55^{\mathrm{e}}$ & $13.56 \pm 5.31^{\mathrm{e}}$ & $28.19 \pm 4.49^{\mathrm{e}}$ & $5.86 \pm 0.58^{\mathrm{e}}$ \\
\hline Yeast & $5.36 \pm 0.12^{\mathrm{f}}$ & $1.80 \pm 0.24^{\mathrm{f}, \mathrm{g}}$ & $77.19 \pm 1.66^{\mathrm{f,g,h}}$ & $14.35 \pm 2.04^{\mathrm{f}}$ & $1.30 \pm 0.94^{\mathrm{f}}$ \\
\hline Wheat flour & $8.34 \pm 0.16^{\mathrm{g}, \mathrm{h}}$ & $1.57 \pm 0.38^{\mathrm{f}, \mathrm{g}}$ & $80.18 \pm 2.81^{\mathrm{f}, \mathrm{g}, \mathrm{h}}$ & $9.51 \pm 1.47^{\mathrm{g}, \mathrm{h}}$ & $0.39 \pm 0.08^{\mathrm{g}}$ \\
\hline Corn flour & $8.39 \pm 1.01^{\mathrm{g}, \mathrm{h}}$ & $5.56 \pm 0.68^{\mathrm{h}}$ & $76.79 \pm 0.47^{\mathrm{f}, \mathrm{g}, \mathrm{h}}$ & $8.49 \pm 2.74^{\mathrm{g}, \mathrm{h}}$ & $0.77 \pm 0.04^{\mathrm{h}}$ \\
\hline
\end{tabular}

The same superscripts after the values indicate no significant difference

Table 3 Proximate composition (\%) of adult P. australis at the start and at the end of the experimental period (mean \pm SD)

\begin{tabular}{|c|c|c|c|c|c|}
\hline Treatment & Protein & Total Lipids & $\begin{array}{l}\text { Total } \\
\text { Carbohydrates }\end{array}$ & Moisture & Ash \\
\hline Initial & $6.99 \pm 0.43^{\mathrm{a}}$ & $1.02 \pm 0.15^{\mathrm{a}}$ & $17.20 \pm 3.47^{\mathrm{c}}$ & $74.04 \pm 3.48^{\mathrm{b}}$ & $0.75 \pm 0.10^{\mathrm{a}, \mathrm{b}, \mathrm{c}}$ \\
\hline Isochrysis galbana (T-ISO) & $24.27 \pm 0.88^{\mathrm{e}}$ & $6.13 \pm 0.53^{\mathrm{e}}$ & $7.03 \pm 0.94^{\mathrm{a}, \mathrm{b}}$ & $62.02 \pm 1.40^{\mathrm{a}}$ & $0.56 \pm 0.05^{\mathrm{d}, \mathrm{e}}$ \\
\hline Pavlova lutheri & $33.75 \pm 0.87^{\mathrm{f}}$ & $5.41 \pm 0.45^{\mathrm{d}, \mathrm{e}}$ & $4.04 \pm 0.20^{\mathrm{a}}$ & $56.10 \pm 0.95^{\mathrm{c}}$ & $0.71 \pm 0.35^{\mathrm{a}, \mathrm{b}, \mathrm{c}, \mathrm{f}, \mathrm{g}, \mathrm{h}, \mathrm{e}}$ \\
\hline Tetraselmis suecica & $10.77 \pm 0.44^{\mathrm{b}}$ & $2.67 \pm 0.81^{\mathrm{b}}$ & $16.32 \pm 2.38^{\mathrm{c}}$ & $69.58 \pm 2.01^{\mathrm{b}}$ & $0.66 \pm 0.16^{\mathrm{a}, \mathrm{b}, \mathrm{f}, \mathrm{c}}$ \\
\hline Chaetoceros muelleri & $14.06 \pm 0.39^{c}$ & $2.92 \pm 0.27^{\mathrm{b}, \mathrm{c}}$ & $10.28 \pm 2.37^{\mathrm{b}, \mathrm{c}}$ & $71.75 \pm 2.30^{\mathrm{b}}$ & $1.00 \pm 0.25^{\mathrm{b}, \mathrm{f}, \mathrm{c}, \mathrm{g}, \mathrm{h}, \mathrm{j}}$ \\
\hline Thalassiosira pseudonana $(3 \mathrm{H})$ & $18.19 \pm 1.60^{\mathrm{d}}$ & $3.33 \pm 0.54^{\mathrm{b}, \mathrm{c}}$ & $7.53 \pm 1.52^{\mathrm{a}, \mathrm{b}}$ & $70.00 \pm 0.29^{\mathrm{b}, \mathrm{d}}$ & $0.94 \pm 0.4^{\mathrm{b}, \mathrm{c}, \mathrm{g}, \mathrm{h}, \mathrm{j}}$ \\
\hline Yeast & $23.47 \pm 1.43^{\mathrm{e}}$ & $4.28 \pm 0.28^{\mathrm{c}, \mathrm{d}}$ & $7.98 \pm 1.58^{\mathrm{a}, \mathrm{b}}$ & $62.89 \pm 0.75^{\mathrm{a}}$ & $1.37 \pm 0.42^{\mathrm{i}}$ \\
\hline Wheat flour & $18.86 \pm 0.28^{\mathrm{d}}$ & $2.08 \pm 0.70^{\mathrm{b}}$ & $13.31 \pm 4.08^{\mathrm{b}, \mathrm{c}}$ & $65.00 \pm 3.92^{\mathrm{a}}$ & $0.75 \pm 0.28^{\mathrm{a}, \mathrm{b}, \mathrm{d}}$ \\
\hline Corn flour & $18.92 \pm 0.39^{\mathrm{d}}$ & $4.46 \pm 0.36^{\mathrm{c}, \mathrm{d}, \mathrm{e}}$ & $7.90 \pm 1.49^{\mathrm{a}, \mathrm{b}}$ & $67.83 \pm 1.49^{\mathrm{a}}$ & $0.89 \pm 0.32^{\mathrm{g}, \mathrm{h}, \mathrm{j}}$ \\
\hline Starved & $7.53 \pm 0.28^{\mathrm{b}}$ & $0.90 \pm 0.14^{\mathrm{a}}$ & $12.18 \pm 3.97^{\mathrm{b}, \mathrm{c}}$ & $78.78 \pm 4.04^{\mathrm{a}, \mathrm{e}}$ & $0.62 \pm 0.08^{\mathrm{c}, \mathrm{d}, \mathrm{j}}$ \\
\hline
\end{tabular}

The same superscripts after the values indicate no significant difference 
The moisture content in starved clams was the highest in the initial value $(82.33 \pm 0.86 \%)$ and the moisture decreased for all treatment groups during the final 21 st day of the feeding trial. Ash content in clams fed $C$. muelleri was $1.00 \pm 0.32 \%$, and did not differ significantly from the values obtained in clams fed T. pseudonana $(0.94 \pm 0.48 \%)$ and corn flour $(0.89 \pm 0.32 \%)(p>0.05)$.

\section{Discussion}

Effects of the different diets on growth and mortality

Results of these experiments demonstrate that the processed diets (yeast, wheat flour, and corn flour) are potential substitutes for laboratory-grown pipi. The use of yeast for spat pipi, for example, showed similar shell growth as those fed I. galbana $(p>0.05)$. Spat fed wheat and corn flours showed no differences in shell growth when compared to those fed the microalgal diets, except for I. galbana $(p<0.05)$. For juveniles, the corn flour fed animals had similar weight gain with I. galbana $(p>0.05)$. Microalga I. galbana was the main source of energy for a great weight gain in juvenile pipi (Fig. 1d). All fed clams, regardless of size class, grew relatively better than the no-food control. It was apparent that $P$. lutheri microalga mostly supported weight gains for all size classes.

In general, spat and juvenile pipi grew faster than adults. During the earlier life stages (larvae, spat, and juveniles), nutrients derived from diets are catabolised to provide energy for growth. The same growth pattern has been observed in other bivalve species such as in the rock-boring clam Penitella penita (Evans 1968), the fingernail clam Sphaerium striatinum (Hornbach et al. 1983), the Asiatic clam Corbicula fluminea (Welch and Joy 1984), the hard clam Mercenaria mercenaria (Lorio and Malone 1995), the Antarctic clam Laternula elliptica (Ahn and Shim 1998), the black clam Villorita cyprinoides (Arun 2009).

The uses of yeast, wheat flour, and corn flour have been reported as potential substitutes for microalgae in other bivalve species. For example, Perez-Camacho et al. (1998) suggested the use of corn-based diet to substitute $50 \%$ of the $2 \%$ phytoplankton daily ration in the little neck clam, Ruditapes decussatus. In another study, Albentosa et al. (2002) found no significant difference between spat fed $100 \%$ I. galbana and a mixed diet consisting of $50 \%$ I. galbana and $50 \%$ wheat germ flour, in the Manila clam (Ruditapes philippinarum). In respect to substituting yeast for microalgal diets, many studies have shown positive results for growth in R. philippinarum (Coutteau and Sorgeloos 1992), the hard clam M. mercenaria (Epifanio 1979; Coutteau et al. 1994), the blue mussel Mytilus edulis (Epifanio 1979), the bay scallop Argopecten irradians (Epifanio 1979), the Pacific oyster Crassostrea gigas (Coutteau et al. 1993), and the Sydney rock oyster Saccostrea commercialis (Brown et al. 1996). However, growth in the soft tissue of C. gigas oysters decreased with the increasing amount of yeast in the diet (Epifanio 1979).

Effect of dietary contents of the diets on growth performance

High protein contents in dietary microalgae were reported to enhance growth performance in the short-neck clam Tapes japonica (Gallager and Mann 1981), the Pacific oyster Crassostrea virginica (Webb and Chu 1983), the European flat oyster Ostrea edulis (Enright et al. 1986), and the Mediterranean mussel Mytilus galloprovincialis (Langdon and Onal 1999) juveniles. On the other hand, Uriarte and Farias (1999), working with the scallop Argopecten purpuratus, and Ceron-Ortiz et al. (2009) with Lyropecten subnodosus, found that spat of both species grew relatively better with higher lipid levels in the diets. On the basis of proximate composition of the experimental diets used in this study (Table 2), it is speculated that lipids play a major role in determining weight gain in spat and juveniles. In support to this, growth of Ostrea edulis spat also was influenced by the amount of lipids in larval tissues during metamorphosis and in the diets (Laing and Millican 1986). Similarly, a significant correlation between growth and dietary lipid content was observed in $C$. virginica spat (Wikfors et al. 1984). However, Waldock and Nascimento (1979) and Langdon and Waldock (1981) found that level of lipids in diets was negatively correlated with growth rates of $C$. gigas larvae and spat.

Conversely, adult pipi obtained higher growth with diet containing high carbohydrate level, particularly corn flour. These positive results propose the commercial application of corn flour in diets of pipi, mainly for adults. Carbohydrates are important to balance the utilisation of proteins and lipids in catabolic pathways for 
energy production (Whyte et al. 1989) and also regarded as the principal energy reserve for adult marine bivalves; both for gametogenesis and during food deficiency especially in winter time (Reid 1969).

Effect of the diets on body composition of adult pipi

Proximate analysis of adult pipi revealed that proteins and lipids were accumulated in the tissue of the fed groups, while carbohydrate levels depleted in all treatments including the control group. The concomitant increase in the levels of proteins and lipids and carbohydrate depletions, were profoundly due to accumulation of mature oocytes. These results suggest that the adults may have initiated their gonadal development. This conforms with other studies where accumulations of proteins in bivalve tissue are simultaneously an indicator to maturation of gonads (Devi et al. 1985; Kreeger 1993; Rivonker and Parulekar 1995), and as a reserve prior to spawning activity (Nagabhushnam and Mane 1978; Gabbott and Peek 1991). Proteins and lipids were continuously metabolised to support energy demand whenever needed (food scarcity or insufficient carbohydrates).

Meanwhile, carbohydrates in adult tissue were rapidly catabolised to meet the energy requirements for reproduction. Similar observations were made by Rodriguez et al. (1993) who regarded carbohydrates as the main energy source for gametogenesis in clams Tapes decussatus and R. philippinarum. For adult oysters, cornstarch feeds have been used to complement natural microalgae to improve condition index of the animals (Haven 1965; Ingle 1967; Dunathan et al. 1969). These findings emphasised the importance of carbohydrates accumulation as energy reserves in the form of glucogen in gametogenesis (Gabbott 1975). Starvation in adult pipi resulted to expenditures of lipid and carbohydrate resources. This is explained by the functions of lipids and carbohydrates during food scarcity (Whyte et al. 1990).

Microalgal and substitute diets

In recent years, there have been numerous studies on microalgal replacements for bivalve cultures. Among these, partial substitutions with alternative diets have been studied in other clam species such as $R$. philippinarum (Albentosa et al. 1989, 2002), R. decussatus (Albentosa et al. 1999), C. fluminea (Foe and Knight 1986), and M. mercenaria (Coutteau et al. 1991). The use of low-cost processed diets used in the present study would allow an increase in pipi production in hatcheries by reducing the operational costs.

In conclusion, microalgae are still the main nutrient sources for pipi, particularly for spat and juveniles. It is also suggested that corn flour should be considered in the formulation of diets for laboratory-grown pipi. The outcomes of this study are useful in providing better understandings on nutrients required by pipi and proposing the use of processed diets in their feeding.

Acknowledgments We thank Adam Rusk for providing assistance in culturing microalgae and technical support during hatchery cultivation of pipi. We also appreciate assistance from Tim Young regarding proximate analysis. The microalgae were obtained from CSIRO Microalgae Research Centre, Tasmania, Australia.

Open Access This article is distributed under the terms of the Creative Commons Attribution License which permits any use, distribution, and reproduction in any medium, provided the original author(s) and the source are credited.

\section{References}

Ahn IY, Shim JH (1998) Summer metabolism of the Antarctic clam, Laternula elliptica (King and Broderip) in Maxwell Bay, King George Island and its implications. J Exp Mar Biol Ecol 224(2):253-264. doi:10.1016/S0022-0981(97)00201-3

Albentosa M, Naessens E, Leger P, Coutteau P, Lavens P, Sorgeloos P (1989) Promising results in the seed culturing of the Manila clam Tapes semidecussata with a manipulated yeast product as a partial substitute for algae. Eur Aquac Soc Spec Publ 10:7-8

Albentosa M, Fernandez-Reiriz MJ, Perez-Camacho A, Labarta U (1999) Growth performance and biochemical composition of Ruditapes decussatus spat fed on microalgal and wheatgerm flour diets. J Exp Mar Biol Ecol 232:23-37. doi:10.1016/S00220981(98)00086-0

Albentosa M, Perez-Camacho A, Fernandez-Reiriz MJ, Labarta U (2002) Wheatgerm flour in diets for Manila clam, Ruditapes philippinarum spat. Aquaculture 212(1-4):335-345. doi:10.1016/S0044-8486(02)00121-7

AOAC (2005) Official Methods of Analysis of Aoac International, 18th edn. AOAC International, Maryland 
Arun A (2009) An assessment on the influence of salinity in the growth of black clam (Villorita cyprinoides) in cage in Cochin Estuary with a special emphasis on the impact of Thanneermukkom salinity barrier. Aquac Aquar Conserv Legis Int $\mathbf{J}$ Bioflux Soc 2(3):319-330

Bligh EG, Dyer WJ (1959) A rapid method of total lipid extraction and purification. Can J Biochem Physiol 39:911-917. doi:10. 1139/059-099

Brown MR, Barrett SM, Volkma JK, Nearhos SP, Nell JA, Allan GL (1996) Biochemical composition of new yeasts and bacteria as food for bivalve aquaculture. Aquaculture 143:341-360. doi:10.1016/0044-8486(96)01286-0

Caers M, Coutteau P, Sorgeloos P (1999) Dietary impact of algal and artificial diets, fed at different feeding rations, on the growth and fatty acid composition of Tapes philippinarum (L). spat. Aquaculture 170:307-322. doi:10.1016/S0044-8486(98)00410-4

Ceron-Ortiz AN, Cordero B, Arredondo-Vega BO, Voltolina D (2009) Effect of algal diet and temperature on survival, growth and biochemical composition of spat of the lion's paw scallop Nodipecten subnodosus. Aquaculture 298(1-2):64-69. doi:10. 1016/j.aquaculture.2009.10.006

Coutteau P, Sorgeloos P (1992) The use of algal substitutes and the requirement for live algae in the hatchery and nursery rearing of bivalve molluscs: and international survey. J Shellfish Res 11:467-476

Coutteau P, Hadley NH, Manzi JJ, Sorgeloos P (1991) Manipulated yeast diets as a partial algal substitute for the nursery culture of the hard clam Mercenaria mercenaria. Spec Publ Eur Aquac Soc 14:77-78

Coutteau P, Dravers M, Dravers P, Leger P, Sorgeloos P (1993) Manipulated yeast diets and dried algae as a partial substitute for live algae in the juvenile rearing of the Manila clam Tapes philippinarum and the Pacific oyster Crassostrea gigas. In: Barnabe G, Kestemont P (eds) Production, environment and quality, vol 92. Bordeaux Aquaculture, pp 523-531

Coutteau P, Hadley NH, Manzi JJ, Sorgeloos P (1994) Effect of algal ration and substitution of algae by manipulated yeast diets on the growth of juvenile Mercenaria mercenaria. Aquaculture 120:135-150. doi:10.1016/0044-8486(94)90229-1

Devi VU, Rao YP, Rao DGVP (1985) Seasonal changes in the biochemical composition of a tropical intertidal prosobranch Morula granulata (Duclos). J Molluscan Stud 51:248-256

Dunathan JP, Ingle RM, Havens WK Jr (1969) Effects of artificial foods upon oyster fattening with potential commercial applications. Florida Board of Conservation. Mar Res Lab 58:1-38

Enright CT, Newkirk GF, Craigier JS, Castell JD (1986) Growth of juvenile Ostrea edulis L. fed Chaetoceros gracilis Schütt of varied chemical composition. J Exp Mar Biol Ecol 96(1):15-26. doi:10.1016/0022-0981(86)90010-9

Epifanio C (1979) Comparison of yeast and algal diets for bivalve molluscs. Aquaculture 16:187-192. doi:10.1016/00448486(79)90106-6

Evans JW (1968) The effect of rock hardness and other factors on the shape of the burrow of the rock-boring clam, Penitella penita. Palaeogeogr Palaeoclimatol Palaeoecol 4(4):271-278. doi:10.1016/0031-0182(68)90094-1

FAO (2003) Food energy - methods of analysis and conversion factors. Report of a Technical Workshop, Rome, 3-6 December 2002

Foe C, Knight A (1986) Growth of Corbicula fluminea (Bivalvia) fed artificial and algal diets. Hydrobiologia 133:155-164. doi:10.1007/BF00031864

Gabbott PA (1975) Storage cycles in marine bivalve molluscs: a hypothesis concerning the relationship between glycogen metabolism and gametogenesis. In: Barnes H (ed) Ninth European Marine Biology Symposium. Aberdeen University Press, Aberdeen, pp 191-211

Gabbott PA, Peek K (1991) Cellular biochemistry of the mantle tissue of the mussel Mytilus edulis L. Aquaculture 94(2-3):165-176. doi:10.1016/0044-8486(91)90116-O

Gallager SM, Mann R (1981) The effect of varying carbon-nitrogen ratio in the phytoplankter Thalassiosira pseudonana (3H) on its food value to the bivalve Tapes japonica. Aquaculture 26(1):95-105. doi:10.1016/0044-8486(81)90113-7

Guillard R (1975) Culture methods. In: Hallegraeff G, Anderson D, Cembella A (eds) Manual on harmful marine microalgae. IOC Manual and Guides No. 33. Paris, UNESCO, pp 45-62

Haven DS (1965) Supplemental feeding of oysters with starch. Chesapeake Scie 6:43-51. doi:10.2307/1350622

Hewitt J, Pridmore R, Thrush S, Cummings V (1997) Assessing the short-term stability of spatial patterns of macrobenthos in a dynamic estuarine system. Limnol Oceanogr 42(2):282-288

Hooker SH (1995) Life history and demography of the pipi Paphies australis (Gmelin, 1790) (Bivalvia: Mesodesmatidae). PhD thesis. Auckland: University of Auckland

Hornbach DJ, Wissing TE, Burky AJ (1983) Seasonal variation in the metabolic rates and $\mathrm{Q}_{10^{-}}$values of the fingernail clam, Sphaerium striatinum Lamarck. Comp Biochem Physiol A Physiol 76(4):783-790. doi:10.1016/0300-9629(83)90141-X

Hull PJ, Cole RG, Creese RG, Healy TR (1998) An experimental investigation of the burrowing behaviour of Paphies australis (Bivalvia: Mesodesmatidae). Mar Freshw Behav Physiol 31(3):167-183. doi:10.1080/10236249809387071

Ingle RM (1967) Artificial food for oysters. Sea Front 13:296-303

Kreeger DA (1993) Seasonal patterns in utilization of dietary protein by the mussel Mytilus trossulus. Mar Ecol Prog Ser 95:215-232. doi:10.3354/meps 126177

Laing I, Millican PF (1986) Relative growth and growth efficiency of Ostrea edulis L. spat fed various algal diets. Aquaculture 54(4):245-262. doi:10.1016/0044-8486(86)90270-X

Langdon CJ, Onal E (1999) Replacement of living microalgae with spray-dried diets for the marine mussel Mytilus galloprovincialis. Aquaculture 180(3-4):283-294. doi:10.1016/S0044-8486(99)00197-0

Langdon CJ, Waldock MJ (1981) The effect of algal and artificial diets on the growth and fatty acid composition of Crassostrea gigas spat. J Mar Biol Assoc UK 61:431-448

Lorio WJ, Malone S (1995) Biology and culture of the northern quahog clam (Mercenaria mercenaria). SRAC Publ Number, Southern Regional Aquaculture Center 433 
Mazon-Suastegui JM, Ruiz-Ruiz KM, Parres-Haro A, Saucedo PE (2008) Combined effects of diet and stocking density on growth and biochemical composition of spat of the Cortez oyster Crassostrea corteziensis at the hatchery. Aquaculture 284(1-4):98-105. doi:10.1016/j.aquaculture.2008.07.022

McLeod R, Wing S (2008) Influence of an altered salinity regime on the population structure of two infaunal bivalve species. Estuar Coast Shelf Sci 78(3):529-540. doi:10.1016/j.ecss.2008.01.019

Nagabhushnam R, Mane UH (1978) Seasonal variation in the biochemical composition of Mytilus viridis at Ratnagiri on the West Coast of India. Hydrobiologia 57(1):69-72. doi:10.1007/BF00018630

Nevejan NM, Pronker AS, Peene F (2008) Hatchery broodstock conditioning of the blue mussel Mytilus edulis (Linnaeus, 1758). Part II. New formulated feeds offer new perspectives to commercial hatcheries. Aquac Int 16(6):483495. doi:10.1007/ s10499-007-9160-8

Pales-Espinosa E, Allam B (2006) Comparative growth and survival of juvenile had clams, Mercenaria mercenaria, fed commercially available diets. Zoo Biol 25:513-525. doi:10.1002/zoo.20113

Perez-Camacho A, Albentosa M, Fernandez-Reiriz MJ, Labarta U (1998) Effect of microalgal and inert (cornmeal and cornstarch) diets on growth performance and biochemical composition of Ruditapes decussatus seed. Aquaculture 160(1-2):89-102. doi:10.1016/S0044-8486(97)00232-9

Reid RGB (1969) Seasonal observations on diet, and stored glycogen and lipids in the horse clam, Tresus capax (Gould, 1850). Veliger 11:378-381

Rivonker CU, Parulekar AH (1995) Proximate biochemical composition and caloric potential in the raft-grown green mussel Perna viridis. J Mar Biol Assoc India 37:231-236. http://drs.nio.org/drs/handle/2264/2304

Rodriguez ME, Arnaiz R, Coo A, Martinez D, Silva A, Varela JA (1993) Proceso de maduración y acondicionamiento de Tapes decussatus (Linné, 1787), fuera de época natural: I. Histoquímica, histología y composición bioquímica. In: Cerviño A, Landín A, de Coo A, Guerra A, Torre M (eds) Proc. IV Nat. Congress Aquaculture, 21-24 September 1993. Consellería de Pesca, Marisqueo e Acuicultura, Xunta de Galicia, España, pp 335-340

Uriarte I, Farias A (1999) The effect of dietary protein content on growth and biochemical composition of Chilean scallop Argopecten purpuratus (L.) postlarvae and spat. Aquaculture 180(1-2):119-127. doi:10.1016/S0044-8486(99)00145-3

Waldock MJ, Nascimento IA (1979) The triacylglycerol composition of Crassostrea gigas larvae fed on different algal diets. Mar Biol Lett 1:77-86

Webb KL, Chu FE (1983) Phytoplankton as a food source for bivalve larvae. In: Pruder GD, Langdon CJ, Conklin D (eds) Biochemical and physiological approaches to shellfish nutrition. Proceedings of the second international conference on aquaculture nutrition, pp 272-291

Welch KJ, Joy JE (1984) Growth Rates of the Asiatic Clam, Corbicula fluminea (Muller), in the Kanawha River, West Virginia. Freshw Invertebr Biol 3(3):139-142

Whyte JNC, Bourne N, Hodgson CA (1989) Influence of algal diets on biochemical composition and energy reserves in Patinopecten yessoensis (Jay) larvae. Aquaculture 78(3-4):333-347. doi:10.1016/0044-8486(89)90110-5

Whyte JNC, Bourne N, Hodgson CA (1990) Nutritional condition of rock scallop, Crassadoma gigantea (Gray), larvae fed mixed algal diets. Aquaculture 86:25-40. doi:10.1016/0044-8486(90)90219-D

Wikfors GH, Twarog JW Jr, Ukeles R (1984) Influence of chemical composition of algal food sources on growth of juvenile oysters, Crassostrea virginica. Biol Bull 167:251-263 